\title{
Carbon Storage and Sequestration of Urban Street Trees in Beijing, China
}

\author{
Yujia Tang ${ }^{1}$, Anping Chen ${ }^{2,3}$ and Shuqing Zhao ${ }^{1 *}$ \\ ${ }^{1}$ Key Laboratory for Earth Surface Processes of the Ministry of Education, College of Urban and Environmental Sciences, \\ Peking University, Beijing, China, ${ }^{2}$ The Woods Hole Research Center, Falmouth, MA, USA, ${ }^{3}$ Department of Ecology and \\ Evolutionary Biology, Princeton University, Princeton, NJ, USA
}

\section{OPEN ACCESS}

Edited by:

Jeremy Lundholm,

Saint Mary's University, Canada

Reviewed by:

Anna L. Johnson,

University of Maryland, USA

Diane E. Pataki,

University of Utah, USA

*Correspondence:

Shuaing Zhao

sqzhao@urban.pku.edu.cn

Specialty section:

This article was submitted to

Urban Ecology,

a section of the journal

Frontiers in Ecology and Evolution

Received: 02 December 2015 Accepted: 26 April 2016 Published: 12 May 2016

Citation:

Tang YJ, Chen AP and Zhao SQ (2016) Carbon Storage and Sequestration of Urban Street Trees in Beijing, China. Front. Ecol. Evol. 4:53. doi: 10.3389/fevo.2016.00053
Anthropogenic carbon dioxide $\left(\mathrm{CO}_{2}\right)$ emissions from cities have significantly increased over the past several decades along with rapid urbanization. To what extent anthropogenic $\mathrm{CO}_{2}$ emissions generated from cities can be offset through conserving or increasing carbon $(\mathrm{C})$ stored within urban areas themselves is a significant scientific question. The role of urban street trees in offsetting anthropogenic $\mathrm{CO}_{2}$ emissions still remains uncertain. Here, using data from field surveys, tree growth measurements, and governmental statistical yearbooks, we estimated the $\mathrm{C}$ storage and $\mathrm{C}$ sequestration capacity of street trees in Beijing. Results showed that the $\mathrm{C}$ density and $\mathrm{C}$ sequestration rate in Beijing's urban street trees were about 1/3 1/2 of the corresponding magnitudes of non-urban forests in China. However, the total $\mathrm{C}$ sequestration of street trees in Beijing's urban districts was $3.1 \pm 1.8 \mathrm{Gg} \mathrm{C} \mathrm{yr}^{-1}\left(1 \mathrm{Gg}=10^{9} \mathrm{~g}\right)$ in 2014 , equivalent to only about $0.2 \%$ of its annual $\mathrm{CO}_{2}$-equivalent emissions from total energy consumption, indicating a rather limited role in offsetting overall anthropogenic $\mathrm{CO}_{2}$ emissions.

Keywords: urbanization, carbon cycle, urban vegetation, tree benefits, urban sustainability

\section{INTRODUCTION}

More than half of the world's population now lives in urban areas, and this figure will continue to increase at a rate of $4 \%$ a decade by 2050 (UN, 2015). In China, urban population has grown from 17.4 to $53.7 \%$ between 1975 and 2013, and is expected to reach $60 \%$ by 2030 (SSB, 2014; UN, 2015). Fast urbanization imposes grand societal and environmental challenges such as compromised human health (Gong et al., 2012), alteration of local and regional climate (Chrysanthou et al., 2014; Zhou et al., 2014), loss of natural habitats and biodiversity (Alberti, 2005; Seto et al., 2012) and degradation of water and air quality (Zhao et al., 2006; Young et al., 2012). It is long and widely believed that forest patches in urban areas provide many ecological and social benefits, which partly mitigate urbanization-caused deterioration of the environment (Sanders, 1986; Akbari and Konopacki, 2004; Lohr et al., 2004; Nowak et al., 2013a, 2014). Nevertheless, those benefits might be overstated and potential costs are not clearly quantified (Pataki et al., 2011; Whitlow et al., 2014). Thus, more studies are needed to accurately assess each ecosystem service provided by urban forests and clearly communicate the scientific findings.

Cities are responsible for $\sim 75 \%$ of global anthropogenic carbon dioxide $\left(\mathrm{CO}_{2}\right)$ emissions (Seto et al., 2014). An interesting research topic is to quantify and understand the role of conserving or increasing carbon (C) stored within urban areas themselves in offsetting anthropogenic $\mathrm{CO}_{2}$ emissions generated from cities. In recent decades, there has been much research conducted to quantify the C sequestration of urban forests (Abdollahi et al., 2000; Nowak and Crane, 2002; Pataki et al., 2006; Zhao et al., 2013; Raciti et al., 2014). For example, Davies et al. (2011) found 
that a substantial amount of carbon was stored within aboveground vegetation in Leicester, United Kingdom, and that trees account for more than $95 \%$ of this carbon pool. In some regions, especially arid areas, urban forests may store more carbon than adjacent suburban and rural areas, as a result of tree planting and urban greenspace management (McHale et al., 2009a). A few studies also suggest that vegetation carbon density and carbon accumulation rate in urban forests can be larger than that of adjacent natural forests (Davies et al., 2011; Hutyra et al., 2011). Therefore, accurate quantification of the $\mathrm{C}$ storage in various urban forests is critical to improve our understanding of the role of urban green space in the urban carbon balance. In addition, cities experience elevated temperature (i.e., urban "heat island" warming), $\mathrm{CO}_{2}$ and nitrogen deposition, and are usually intensively managed relative to rural settings (Carreiro and Tripler, 2005; Churkina et al., 2015). These drastic differences between urban and natural systems suggest that characterizing $\mathrm{C}$ dynamics of urban forests is an important component of the carbon cycle science.

Since the 1990s, fine-resolution remote sensing, combined with ground observation data and modeling, has provided a useful way to quantify $\mathrm{C}$ storage and sequestration by urban forests (Brack, 2002; Nowak and Crane, 2002; Myeong et al., 2006; Rao et al., 2013). To illustrate, using field data and photointerpretation of tree cover, Nowak et al. (2013b) estimated that annual sequestration in U.S. urban areas is $25.6 \mathrm{Tg} \mathrm{C}\left(1 \mathrm{Tg}=10^{12}\right.$ g) which is equal to $\$ 2.0$ billion in a carbon market. Similar work has also been conducted in some Chinese cities like Xiamen and Shenyang (Ren et al., 2011; Liu and Li, 2012). However, many of these studies ignored urban street trees which do not form a forest stand. In China, trees outside forests (TOF) including urban street trees store about $1339 \mathrm{Tg} \mathrm{C}, 16.5-20.7 \%$ of China's terrestrial vegetation carbon pool, making them a substantial component in China's C budget (Guo et al., 2014). Hence, it is important to include street trees in quantifying the urban forest C budget.

About 21 million people live in Beijing, the capital of China (BSB, 2015). Over the past three decades, urban area in Beijing has expanded from 801 to $2452 \mathrm{~km}^{2}$, an annual rate of $3.7 \%$ (Wu et al., 2015). According to BSB (2014), forest coverage in Beijing's built-up area has reached $46.8 \%$ by 2013 , and the canopy area of street trees amounts to $19 \%$ of the total area of road greenbelts. Nonetheless, we still do not have an accurate estimate of the carbon storage in Beijing's street trees, which is important for assessing the environmental benefits of urban trees. Hence, in this study we used field surveys, combined with tree growth measurement data and government statistics, to quantify the $\mathrm{C}$ storage and $\mathrm{C}$ sequestration rate of urban street trees in Beijing's urban districts.

\section{DATA AND METHODS}

\section{Study Area}

Beijing is located in the North China Plain between longitudes $115^{\circ} 25^{\prime}-117^{\circ} 30^{\prime} \mathrm{E}$, and latitudes $39^{\circ} 28^{\prime}-41^{\circ} 25^{\prime} \mathrm{N}$. It has a typical warm temperate continental monsoon climate with four distinct seasons. The average annual precipitation is $630 \mathrm{~mm}$, and the mean annual temperature is $11.5^{\circ} \mathrm{C}$. The Beijing municipal government administers an area of $16,807 \mathrm{~km}^{2}$, including six city districts, eight suburban districts and two suburban counties. This study focuses on the six city districts (Dongcheng, Xicheng, Haidian, Chaoyang, Shijingshan, and Fengtai; Figure 1). Dongcheng and Xicheng, located in the center of Beijing, are highly protected from development because of their significant historical and cultural values. Haidian and Chaoyang are designated as rapid growing districts to support important economic and cultural functions of the city. Shijingshan and Fengtai are primary residential districts. A road system that currently contains five ring roads (the 2nd to 6th rings) is an important symbol of Beijing infrastructure, and well separates the old city (heavily urbanized) within the inner 2nd ring from recent developments (suburban area) between the outer 5th and 6th rings. Construction of actinomorphic ring roads often follows rapid urbanization (Figure 2).

\section{Sampling Design}

The field work follows a Stratified Random Sampling. Over the study area, we selected sample sites uniformly with an interval of $2 \mathrm{~km}$ and sampled trees on the closest roads. In total, 204 of the 984 roads in Beijing's six city districts were sampled (Table 1). Related information on the sampling sites is from Beijing Statistical Yearbook of urban landscaping (BSB, 2005).

\section{Carbon Storage and Sequestration}

We randomly selected 10 trees per street. According to our survey, most roads only have a single tree species and two rows of trees. In the rare case of two tree species along a street, we measured five trees for each species. For each tree, species name was recorded, and height, diameter at breast height $(\mathrm{DBH}, 1.3 \mathrm{~m}$ above the ground) and the distance to neighboring trees were measured. Biomass allometric equations for each species were used to calculate the dry biomass of each surveyed tree (Table 2). If there is not an established allometric equation for a single species, we used one from the same genus, or a generalized equation from Wang (2006). Dry biomass was converted to C by multiplying by 0.5 (Nowak and Crane, 2002).

Tree carbon storage for the entire study area can be extrapolated by the length of the greening streets using the formula below.

$$
\begin{gathered}
C_{j}=\frac{\sum_{1}^{10} C_{i}}{\sum_{1}^{10} l_{\text {sample }}} \times l_{\text {green }} \times 2 \\
C_{\text {entire }}=\frac{\sum C_{j}}{\sum l_{\text {green }}} \times L_{\text {entire }} \\
C_{\text {density }}=\frac{C_{\text {entire }}}{S_{\text {area }}}
\end{gathered}
$$

$C_{i}$ is the carbon storage or sequestration of a measured individual tree; $l_{\text {green }}$ is the total greening length of the sampled street; $l_{\text {sample }}$ is the distance between neighboring trees; $C_{j}$ is the carbon storage or sequestration of one road; $l_{\text {entire }}$ is the greening length of all 


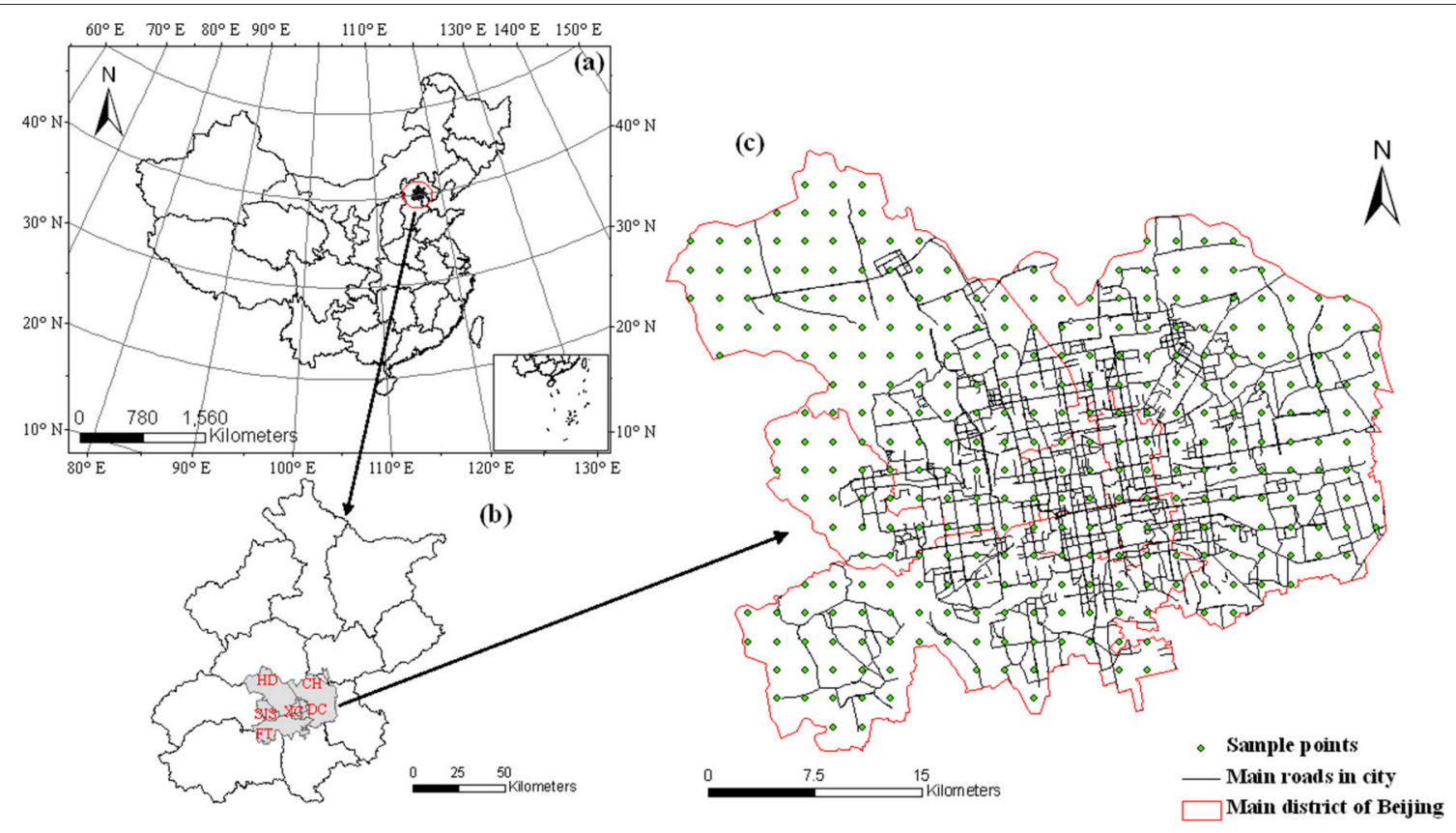

FIGURE 1 | The location of Beijing in China (A), the location of the study area: city districts of Beijing (B), and the sampling design plan (C). District Abbreviations: DC, Dongcheng; XC, Xicheng; CY, Chaoyang; HD, Haidian; FT, Fengtai; SJS, Shijingshan.

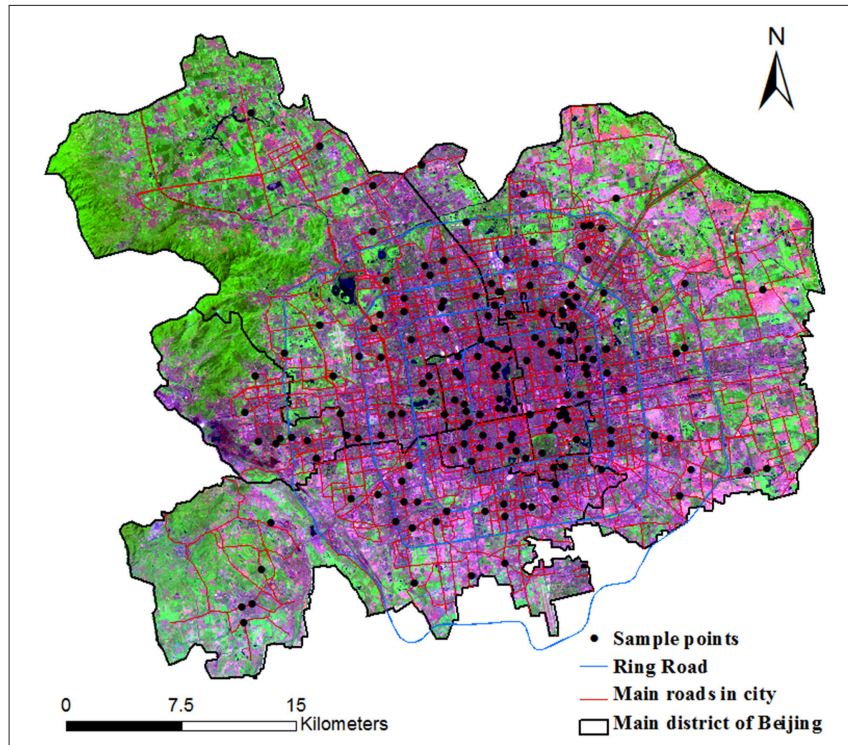

FIGURE 2 | Sampling locations of street trees.

roads in the entire area or a given district; $C_{\text {entire }}$ is the carbon storage or sequestration of the entire area or a given district; and $C_{\text {density }}$ is the density of carbon storage or sequestration of the entire area or a given district. $S_{\text {area }}$ is the total road area of the entire study area or a given district.

Carbon sequestration was estimated based on annual $\mathrm{DBH}$ growth rates (Rowntree and Nowak, 1991). We installed growth rings on 152 trees at five urban parks in Beijing in 2013. The
TABLE 1 | Number and street length of sampled roads.

\begin{tabular}{lcccccc}
\hline \multirow{2}{*}{ District } & \multicolumn{2}{c}{ No. of roads } & & \multicolumn{2}{c}{ Street length (km) } & \multirow{2}{*}{ Area (ha) } \\
\cline { 2 - 3 } & All & Sampled & & All & Sampled & \\
Dongcheng & 137 & 28 & & 120.24 & 28.08 & 480.7 \\
Xicheng & 115 & 30 & & 156.57 & 36.67 & 708.8 \\
Chaoyang & 271 & 61 & & 333.90 & 125.51 & 2011.9 \\
Haidian & 217 & 44 & & 366.25 & 130.47 & 1181.2 \\
Fengtai & 184 & 33 & & 288.30 & 75.32 & 986.9 \\
Shijingshan & 60 & 8 & & 84.63 & 19.15 & 195.6 \\
\hline
\end{tabular}

The area is the total area of roads in each district.

species include Sophora japonica (Linn.), Broussonetia papyrifera (Linn.), and Sabina chinensis (Linn.). DBH increments were measured once a month to ensure accurate quantification of $\mathrm{C}$ sequestration, and an annual average $\mathrm{DBH}$ increment for all species was used to calculate the sequestration. To get the corresponding height increment, we inferred the relationship between $\mathrm{DBH}$ and height from our previous measurements (Table 3). Finally, the increment of tree biomass can be calculated and be converted to carbon sequestration by multiplying by a factor of 0.5 .

\section{RESULTS}

\section{Structure of Urban Street Trees}

We measured 2040 street trees that belong to 12 species. The dominant species sampled is S. japonica (Linn.) which accounts for more than $50 \%$ of the samples. Other common species include 
TABLE 2 | Allometric equations used for biomass estimation in Beijing, China.

\begin{tabular}{lll}
\hline Species & Equation & References \\
\hline $\begin{array}{l}\text { Fraxinus spp. } \\
\text { Sophora japonica }\end{array}$ & $\mathrm{B}=2.1893+3.2949 \times 10^{-2} \mathrm{D}^{2} \mathrm{H}$ & Tabacchi et al., 2011 \\
Linn & He et al., 2007 \\
$\begin{array}{l}\text { Ginkgo biloba } \mathrm{L} \\
\text { Popular spp. }\end{array}$ & $\mathrm{B}=-0.684+0.090 \mathrm{D}^{2} \mathrm{H}$ & He et al., 2007 \\
$\begin{array}{l}\text { Firmiana } \\
\text { platanifolia (L. f.) }\end{array}$ & $\mathrm{B}=0.015 \times\left(\mathrm{gB}=-1.161443+0.913291 \mathrm{lg}\left(\mathrm{D}^{2} \mathrm{H}\right)\right.$ & Li et al., 2007 \\
$\begin{array}{l}\text { Marsili } \\
\text { Generalized }\end{array}$ & $\mathrm{B}=0.11 \times \mathrm{D}^{2.47} \mathrm{H}$ et al., 2006 \\
equation & & Wang, 2006 \\
\hline
\end{tabular}

$B$ is the biomass for the whole tree; $D$ is the diameter at breast height; and $H$ is the total tree height. Generalized equation was applied to Koelreuteria paniculata Laxm., Pinus bungeana Zucc. ex Endl., Salix matsudana Koidz., Ailanthus altissima (Mill.) Swingle, Ulmus pumila Linn., and Acer mono Maxim.

TABLE 3 | Relationship between DBH and height of main tree species.

\begin{tabular}{lccc}
\hline Species & \multicolumn{1}{c}{ Equation } & $\boldsymbol{R}^{\mathbf{2}}$ & Number \\
\hline Sophora japonica Linn & $\mathrm{H}=1.4447 \mathrm{D}^{0.627}$ & 0.54 & 1100 \\
Fraxinus spp. & $\mathrm{H}=1.0022 \mathrm{D}^{0.7787}$ & 0.68 & 265 \\
Ginkgo biloba L & $\mathrm{H}=1.5268 \mathrm{D}^{0.636}$ & 0.66 & 195 \\
Populus spp. & $\mathrm{H}=1.9454 \mathrm{D}^{0.6852}$ & 0.41 & 135 \\
Firmiana platanifolia (L. f.) Marsili & $\mathrm{H}=1.3086 \mathrm{D}^{0.6658}$ & 0.57 & 155 \\
\hline
\end{tabular}

Fraxinus chinensis Roxb., Ginkgo biloba L., and Populus L.. The sampling locations are shown in Figure 2.

Our sampling suggests that street trees in Beijing are mostly dominated by small trees, and the average $\mathrm{DBH}$ of all sampled trees is $23.1 \mathrm{~cm}$. The DBH of more than $80 \%$ trees is $<30 \mathrm{~cm}$ outer 3rd rings (Figure 3). Relationships between $\mathrm{DBH}$ and height of each species are shown in Table 3. The relationships between $\mathrm{DBH}$ and tree height for each species fit power law functions although the exponent and proportionality constant vary between tree species.

\section{Carbon Storage and Sequestration of Urban Street Trees}

The vegetation carbon storage of street trees in Beijing urban districts is $77.1 \pm 4.1 \mathrm{Gg} \mathrm{C}$ with a sequestration rate of $3.1 \pm 1.8$ $\mathrm{Gg} \mathrm{C} \mathrm{yr}^{-1}$. The $\mathrm{C}$ density of street trees is $13.9 \pm 0.7 \mathrm{Mg} \mathrm{C} \mathrm{ha}^{-1}$ with a rate of $0.5 \pm 0.3 \mathrm{MgC} \mathrm{ha}^{-1} \mathrm{yr}^{-1}$.

The street tree $\mathrm{C}$ density of each road is highly heterogeneous, ranging from 0.5 to $200 \mathrm{Mg} \mathrm{ha}^{-1}$. Generally Ginkgo biloba L. and Populus L. trees have a higher density of $\mathrm{C}$ storage because of their larger size. The total C storage and sequestration of street trees in Chaoyang and Haidian are larger than that of the other districts (Figures 4A,B). With the lowest total road area, Shijingshan district has the largest $\mathrm{C}$ storage and sequestration per unit area (Figures 4C,D). Xicheng district has both relatively high $\mathrm{C}$ storage and sequestration for the total as well as per unit area, although Xicheng occupies a relatively small area (Figure 4).

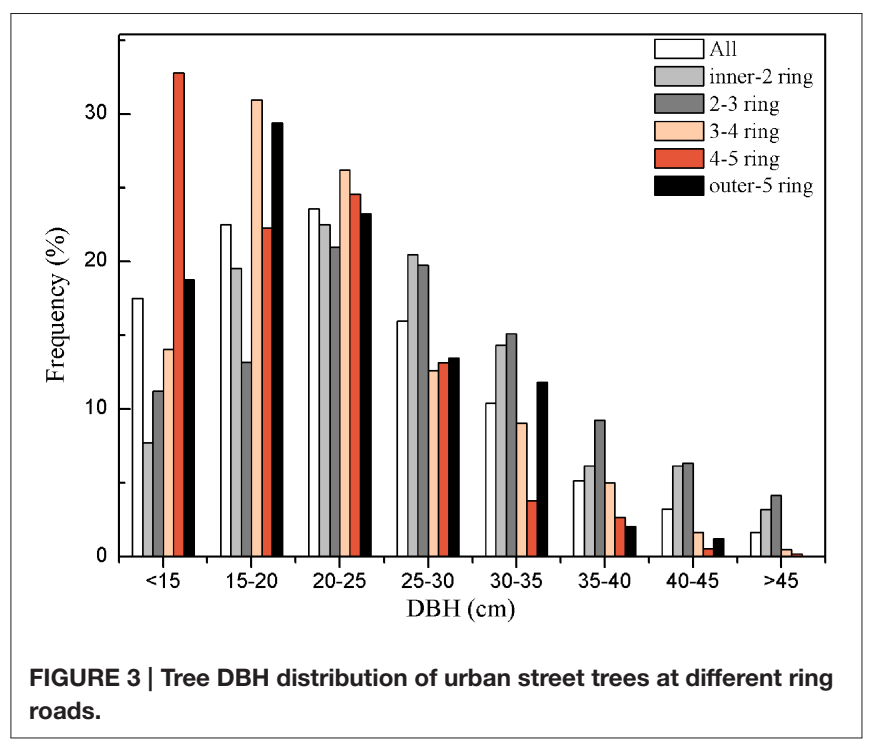

C storage is also highly variable between street trees at different locations, from the inner-2nd ring roads to the outer-5th ring roads (Figure 5). Trees at the 2 nd-3rd ring and the outer5 th ring have a bigger density of $\mathrm{C}$ storage than those located at the 3 rd-4th ring and the 4 th-5th ring. The high-low-high pattern from city-center to suburban is found for both $\mathrm{C}$ density and sequestration rate.

We further investigate three parameters that may be responsible for the spatial heterogeneity in street tree $\mathrm{C}$ density in Beijing: individual tree size, tree density, and the area of road. Results suggest that tree size and tree density are positively correlated with $\mathrm{C}$ density (Figures $\mathbf{6 A , B}$ ), while a power law relationship was observed between $\mathrm{C}$ density and road area with a negative exponent (Figure 6C).

\section{DISCUSSION}

\section{The Potential of Urban Trees to Sequester Carbon}

Urban and urbanizing areas were usually considered as sources of $\mathrm{C}$ emissions. Vegetation of urban areas was largely ignored or assumed to be negligible for the carbon cycle study (Churkina, 2008, 2016; Churkina et al., 2010). Our results suggest that urban street trees in Beijing are $\mathrm{C}$ sinks. The total vegetation $\mathrm{C}$ storage and $\mathrm{C}$ sequestration rate of Beijing city's street trees are $77.1 \pm$ $4.1 \mathrm{Gg} \mathrm{C}$ and $3.1 \pm 1.8 \mathrm{Gg} \mathrm{C} \mathrm{yr}^{-1}$, respectively. The $\mathrm{C}$ density $\left(13.9 \pm 0.7 \mathrm{Mg} \mathrm{C} \mathrm{ha}^{-1}\right)$ and $\mathrm{C}$ sequestration rate $(0.5 \pm 0.3 \mathrm{Mg} \mathrm{C}$ $\mathrm{ha}^{-1} \mathrm{yr}^{-1}$ ) in Beijing's urban street trees were about $1 / 3 \sim 1 / 2$ of the corresponding magnitudes $\left(40.1 \mathrm{Mg} \mathrm{C} \mathrm{ha}^{-1}\right.$ and $1.07 \mathrm{Mg} \mathrm{C}$ $\mathrm{ha}^{-1} \mathrm{yr}^{-1}$ ) of non-urban forests in China (Zhang et al., 2013). Trees in urban ecosystems are exposed to higher temperature, carbon concentration, and nitrogen deposition than trees in rural areas (Idso et al., 2002; Lovett et al., 2002). These by-products of urbanization are very likely to promote urban tree growth (Carreiro and Tripler, 2005). In addition, a lower ozone level in urban areas compared to rural environments may also benefit urban tree growth (Gregg et al., 2003). Given these advantages, as 

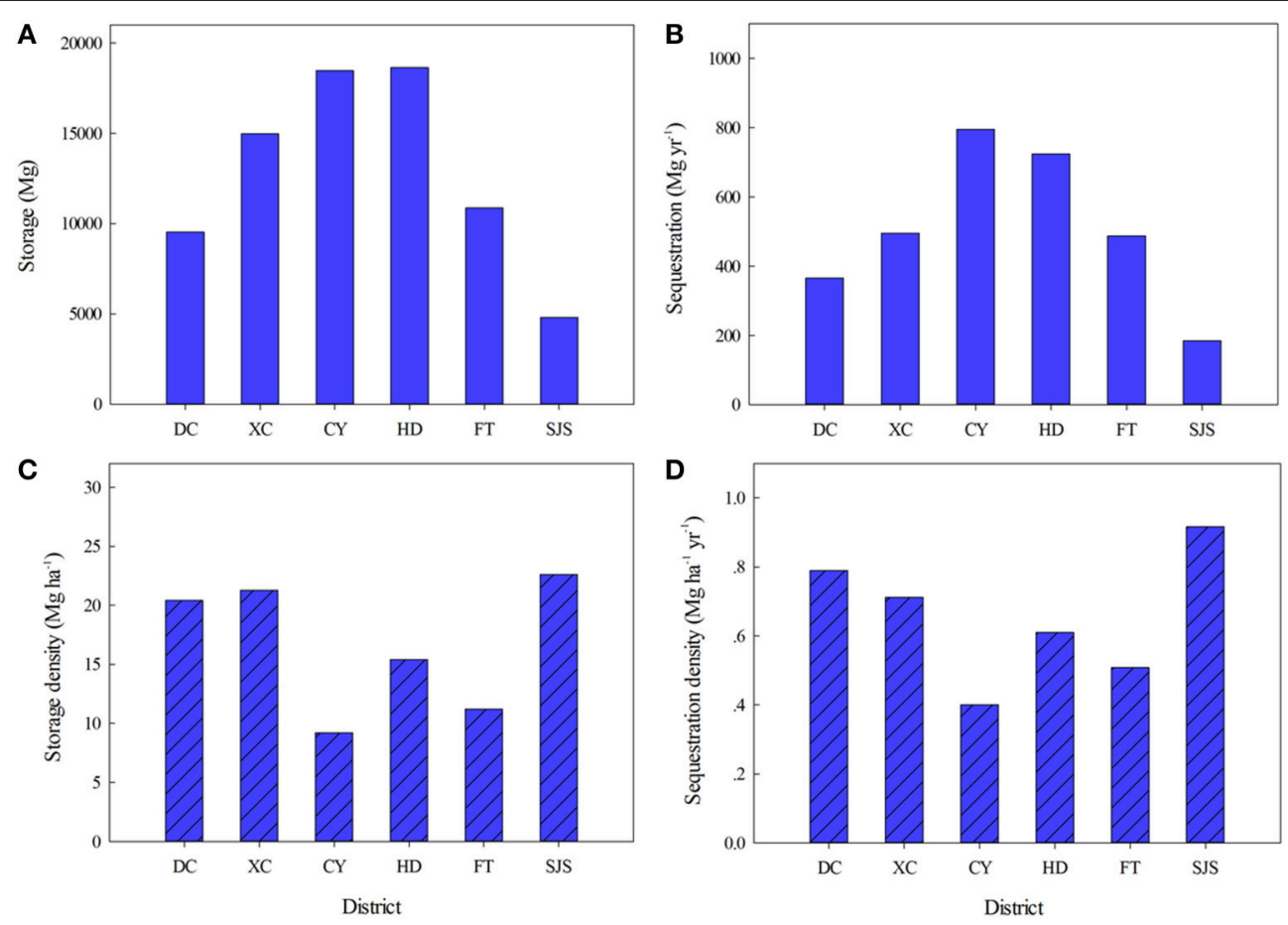

FIGURE 4 | Carbon storage (A) with its density (C) and annual sequestration (B) with its density (D) of street trees at Beijing's six city districts. District Abbreviations: DC, Dongcheng; XC, Xicheng; CY, Chaoyang; HD, Haidian; FT, Fengtai; SJS, Shijingshan.

well as enhanced greening management in urban areas, it is not surprising that the $\mathrm{C}$ density and $\mathrm{C}$ sequestration rate in Beijing's urban street trees were comparable in order of magnitude to those of non-urban forests in China.

According to data from government statistics (BSB, 2012, 2013 , 2014), annual total energy consumed in the six city districts of Beijing between 2012 and 2014 were about $2.97 \times 10^{7}$ tons standard coal which is equal to $18.5 \mathrm{Tg} \mathrm{C}(1 \mathrm{~g}$ standard coal equals to $2.277 \mathrm{~g} \mathrm{CO}_{2}$; Liu and $\mathrm{Li}, 2012$ ). Hence, annual carbon sequestration by Beijing city's street trees can only offset about $0.2 \%$ of Beijing's annual $\mathrm{CO}_{2}$-equivalent emissions from total energy consumed. This ratio is similar to another study in Salt Lake Valley (Pataki et al., 2009), which simulated the effect of doubling the planting density of urban trees in reducing local emissions by 2030 . The $\mathrm{C}$ sequestration of street trees becomes insignificant when compared with the total anthropogenic $\mathrm{CO}_{2}$ emissions and therefore should not be considered as an effective mechanism to offset $\mathrm{CO}_{2}$ emissions. As the local environments and human management activities vary considerably from city to city, more research is needed to better quantify direct $\mathrm{C}$ sequestration potential of urban trees and associated biogeochemical processes across various cities.

\section{Comparisons of Carbon Storage and Sequestration with Other Studies}

The average $\mathrm{C}$ storage and sequestration of individual trees in Beijing city are $130.62 \mathrm{~kg}$ and $5.85 \mathrm{~kg} \mathrm{yr}^{-1}$, respectively, which
TABLE 4 | Density of carbon storage and sequestration capacity for urban forest in different cities.

\begin{tabular}{|c|c|c|c|c|}
\hline City & $\begin{array}{c}\text { Storage } \\
\left(\mathrm{Mg} \mathrm{ha}^{-1}\right)\end{array}$ & $\begin{array}{c}\text { Sequestration } \\
\left(\mathrm{Mg} \mathrm{ha}^{-1}\right. \\
\left.\text { year }^{-1}\right)\end{array}$ & $\begin{array}{c}\text { Tree } \\
\text { density } \\
\text { (No./ha) }\end{array}$ & References \\
\hline Beijing, China & 31.9 & 1.3 & 223 & This study \\
\hline $\begin{array}{l}\text { Shenyang, } \\
\text { China }\end{array}$ & 33.22 & 2.84 & 569 & Liu and Li, 2012 \\
\hline $\begin{array}{l}\text { Hangzhou, } \\
\text { China }\end{array}$ & 30.25 & 1.66 & 465 & Zhao et al., 2010 \\
\hline Daegu, Korea & 24.9 & NA & NA & Yoon et al., 2013 \\
\hline Baltimore, US & 25.28 & 0.71 & 136 & Nowak and Crane, 2002 \\
\hline Atlanta, US & 35.74 & 1.23 & 276 & Nowak and Crane, 2002 \\
\hline Jersey city, US & 5.02 & 0.21 & 36 & Nowak and Crane, 2002 \\
\hline
\end{tabular}

Beijing, China is the extrapolated value, based on the value of urban street trees in this study, and the percentages of green space in urban streets and all urban areas. NA means no data.

are slightly lower than comparative results from Europe (138.62$377.14 \mathrm{~kg}$ per tree and $9.7-30.69 \mathrm{~kg} \mathrm{yr}^{-1}$ per tree, respectively; Russo et al., 2014). This might be attributed to the differences in methodology (field measurement or modeling approach), tree species and tree age. For example, the 3rd-5th rings of Beijing are in fast development and roads are generally broader and planted with younger trees. The relatively lower C storage per tree in Beijing's new construction areas is also corroborated by another study which showed an average $C$ storage per tree in the fourth ring road area (the area between the third ring 

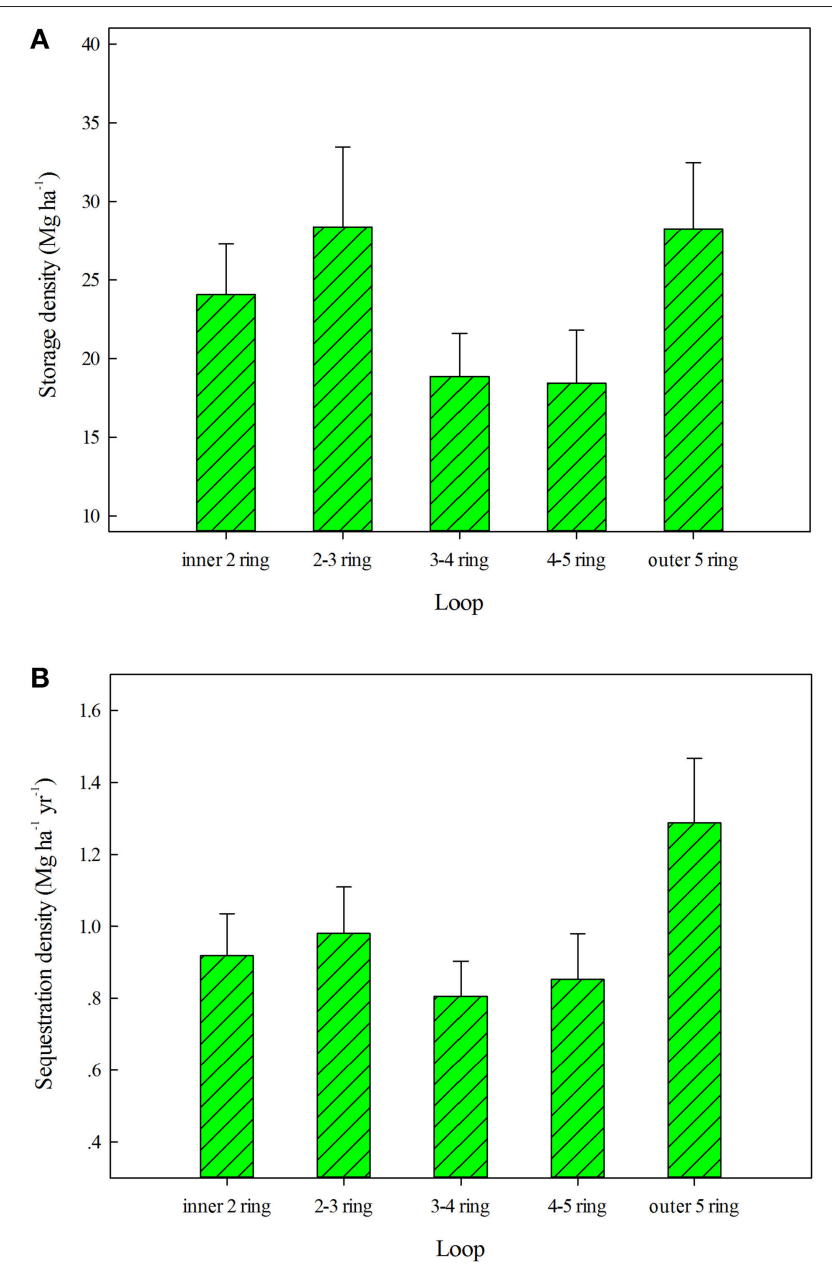

FIGURE 5 | Density of carbon storage (A) and annual carbon sequestration $(B)$ from the inner 2 nd-ring and the outer 5 th-ring roads.

road and the fourth ring road) of only $84.2 \mathrm{~kg}$ (Yang et al., 2005).

Few studies have specifically focused on the density of $\mathrm{C}$ stock and sequestration in urban street trees (Soares et al., 2011). The density of $\mathrm{C}$ storage and sequestration of urban forests are shown in Table 4. In order to make our results comparative within as well as outside of this study, we use the value extrapolated to total area of the urban districts. The comparison suggests that $\mathrm{C}$ storage and sequestration per unit for urban trees in Beijing is at a higher level relative to other cities (Table 4), which might relate to the fact that in Beijing, the street tree planting protocol usually sets tree interval from 3 to $5 \mathrm{~m}$ which makes tree density in Beijing higher.

\section{Some Limits of the Study}

Despite of our tremendous efforts in accurately measuring and quantifying $\mathrm{C}$ stocks and annual $\mathrm{C}$ sequestrations by Beijing's city street trees, there are still several caveats in the current study. For instance, the increment of annual DBH growth was derived from data of only 2 year measurements, and only the
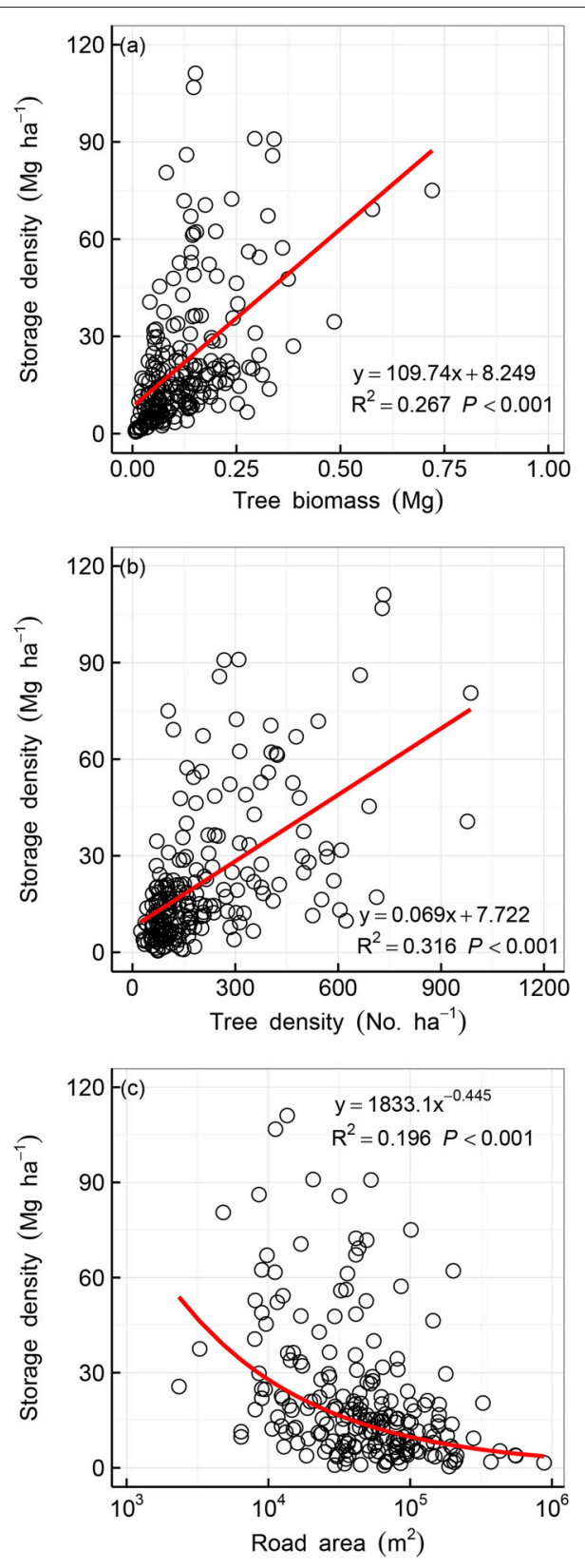

FIGURE 6 | Relationships between carbon density and tree size (A), tree density (B), and road area (C).

mean value of all trees regardless of their species was used in the study due to the limited quantity of trees measured. Thus our results of tree DBH growth for the street trees in Beijing may not be representative enough, and any comparison based on that shall be interpreted with carefulness. Secondly, the annual height increment in this study is derived from the linear DBH-height relationships inferred from our data. The DBH-height equations can be another source of uncertainties (Peng et al., 2001). Thirdly, the $\mathrm{C}$ stock and sequestration estimates for urban trees were based on allometric equations developed from non-urban forests that may not be adequate for urban trees (McHale et al., 2009b). 
Nonetheless, despite of all these uncertainties and caveats, the $\mathrm{C}$ sequestration rate in our study is within the range from previous studies on similar temperate urban trees (Whitford et al., 2001).

\section{CONCLUSIONS}

In the six city districts of Beijing, $\mathrm{C}$ stored and sequestrated by street trees is about $77.1 \pm 4.1 \mathrm{Gg} \mathrm{C}$ and $3.1 \pm 1.8 \mathrm{Gg}$ C $\mathrm{yr}^{-1}$, respectively. The $\mathrm{C}$ sequestration of street trees per unit area in Beijing is comparable in order of magnitude to that of non-urban forests. However, the annual net carbon sequestration in urban street trees across the entirety of Beijing's urban districts is equal to only $0.2 \%$ of its annual $\mathrm{CO}_{2}$-equivalent emissions from total energy consumption. It should be realized that the $\mathrm{C}$ sequestration of street trees becomes insignificant when compared with the total anthropogenic $\mathrm{CO}_{2}$ emissions and therefore should not be considered as an effective mechanism to offset $\mathrm{CO}_{2}$ emissions in Beijing.

Site and species specific allometric equation and growth rate are a key perquisite for accurately estimating $\mathrm{C}$ storage and

\section{REFERENCES}

Abdollahi, K. K., Ning, Z. H., and Appeaning, A. (2000). Global Climate Change and the Urban Forest. Baton Rouge: GCRCC; Franklin Press.

Akbari, H., and Konopacki, S. (2004). Energy effects of heat-island reduction strategies in Toronto, Canada. Energy 29, 191-210. doi: 10.1016/j.energy.2003.09.004

Alberti, M. (2005). The effects of urban patterns on ecosystem function. Int. Reg. Sci. Rev. 28, 168-192. doi: 10.1177/0160017605275160

Beijing Statistical Bureau (BSB) (2005). Beijing Statistical Yearbook of Urban Landscaping. Beijing: China Statistics Press.

Beijing Statistical Bureau (BSB) (2012). Beijing Statistical Yearbook. Beijing: China Statistics Press.

Beijing Statistical Bureau (BSB) (2013). Beijing Statistical Yearbook. Beijing: China Statistics Press.

Beijing Statistical Bureau (BSB) (2014). Beijing Statistical Yearbook. Beijing: China Statistics Press.

Beijing Statistical Bureau (BSB) (2015). Beijing Statistical Yearbook. Beijing: China Statistics Press.

Brack, C. L. (2002). Pollution mitigation and carbon sequestration by an urban forest. Environ. Pollut. 116, S195-S200. doi: 10.1016/S0269-7491(01)00251-2

Carreiro, M. M., and Tripler, C. E. (2005). Forest remnants along urban-rural gradients: examining their potential for global change research. Ecosystems 8, 568-582. doi: 10.1007/s10021-003-0172-6

Chrysanthou, A., Schrier, G., Besselaar, E. J. M., Klein Tank, A. M. G., and Brandsma, T. (2014). The effects of urbanization on the rise of the European temperature since 1960. Geophys. Res. Lett. 41, 7716-7722. doi: 10.1002/2014GL.061154

Churkina, G. (2008). Modeling the carbon cycle of urban systems. Ecol. Model. 216, 107-113. doi: 10.1016/j.ecolmodel.2008.03.006

Churkina, G. (2016). The role of urbanization in the global carbon cycle. Front. Ecol. Evol. 3:144. doi: 10.3389/fevo.2015.00144

Churkina, G., Brown, D. G., and Keoleian, G. (2010). Carbon stored in human settlements: the conterminous United States. Glob. Chang. Biol. 16, 135-143. doi: $10.1111 / j .1365-2486.2009 .02002 . x$

Churkina, G., Grote, R., Butler, T. M., and Lawrencea, M. (2015). Natural selection? Picking the right trees for urban greening. Environ. Sci. Policy 47, 12-17. doi: 10.1016/j.envsci.2014.10.014

Davies, Z. G., Edmondson, J. L., Heinemeyer, A., Leake, J. R., and Gaston, K. J. (2011). Mapping an urban ecosystem service: quantifying above-ground carbon sequestration of urban trees. Further studies are needed to intensively monitor urban tree growth for a more diversified pool of tree species and develop a more sophisticated allometric growth model for urban trees. Such data and models will improve our understanding of the role of urban trees in the urban carbon balance and carbon cycle science.

\section{AUTHOR CONTRIBUTIONS}

SZ designed research; YT and SZ performed research and analyzed data; YT, SZ, and AC wrote the paper.

\section{ACKNOWLEDGMENTS}

This study was supported by the National Natural Science Foundation of China (\#41571079, \#31321061, and \#41590843) and the 111 Project (B14001). We thank C Wang and S Xie for their help with field measurements, and Alexander Nassikas for polishing the English. storage at a city-wide scale. J. Appl. Ecol. 48, 1125-1134. doi: 10.1111/j.13652664.2011.02021.x

Gong, P., Liang, S., Carlton, E. J., Jiang, Q., Wu, J., Wang, L., et al. (2012). Urbanisation and health in China. Lancet 379, 843-852. doi: 10.1016/S01406736(11)61878-3

Gregg, J. W., Dawson, T. E., and Jones, C. G. (2003). Urbanization effects on tree growth in the vicinity of New York City. Nature 424, 183-187. doi: 1038 /nature 01728

Guo, Z. D., Hu, H. F., Pan, Y. D., Birdsey, R. A., and Fang, J. Y. (2014). Increasing biomass carbon stocks in trees outside forests in China over the last three decades. Biogeosciences 11, 4115-4122. doi: 10.5194/bg-11-4115-2014

He, H. Z., Huang, L. H., Duan, X., and He, R. K. (2007). Study on biomass in main afforestation tree species of the second ring forest-belt of Guiyang. Guizhou Sci. 25, 33-39. doi: 1003-6563(2007)03-0033-07

Hope, D., Gries, C., Casagrande, D., Redman, C. L., Grimm, N. B., and Martin, C. (2006). Drivers of spatial variation in plant diversity across the central Arizona-Phoenix ecosystem. Soc. Nat. Resour. 19, 101-116. doi: 10.1080/08941920500394469

Hutyra, L. R., Yoon, B., and Alberti, M. (2011). Terrestrial carbon stocks across a gradient of urbanization: a study of the Seattle, WA region. Glob. Chang. Biol. 17, 783-797. doi: 10.1111/j.1365-2486.2010.02238.x

Idso, S. B., Idso, C. D., and Balling, R. C. (2002). Seasonal and diurnal variations of near-surface atmospheric $\mathrm{CO}_{2}$ concentration within a residential sector of the urban $\mathrm{CO}_{2}$ dome of Phoenix, AZ, USA. Atmos. Environ. 36, 1655-1660. doi: 10.1016/S1352-2310(02)00159-0

Li, J., Li, C., and Peng, S. (2007). Study on the biomass expansion factor of poplar plantation. J. Nanjing For. Univ. 31, 37-40.

Liu, C., and Li, X. (2012). Carbon storage and sequestration by urban forests in Shenyang, China. Urban For. Urban Gree. 11, 121-128. doi: 10.1016/j.ufug.2011.03.002

Lohr, V. I., Pearson-Mims, C. H., Tarnai, J., and Dillman, D. A. (2004). How urban residents rate and rank the benefits and problems associated with trees in cities. J. Arboric. 30, 28-35.

Lovett, G. M., Weathers, K. C., and Arthur, M. A. (2002). Control of nitrogen loss from forested watersheds by soil carbon: nitrogen ratio and tree species composition. Ecosystems 5, 0712-0718. doi: 10.1007/s10021-002-0153-1

McHale, M. R., Baker, L. A., Koerner, B. A., Li, K., Hall, S. J., and Grimm, N. B. (2009a). "Impacts of urbanization on carbon cycling: a complete carbon budget of the Phoenix metropolitan area," Ecological Society of America Annual Meeting (Albuquerque, NM). 
McHale, M. R., Burke, I. C., Lefsky, M. A., Peper, P. J., and McPherson, E. G. (2009b). Urban forest biomass estimates: is it important to use allometric relationships developed specifically for urban trees? Urban Ecosyst. 12, 95-113. doi: 10.1007/s11252-009-0081-3

Myeong, S., Nowak, D. J., and Duggin, M. J. (2006). A temporal analysis of urban forest carbon storage using remote sensing. Remote Sens. Environ. 101, 277-282. doi: 10.1016/j.rse.2005.12.001

Nowak, D. J., and Crane, D. E. (2002). Carbon storage and sequestration by urban trees in the USA. Environ. Pollut. 116, 381-389. doi: 10.1016/S02697491(01)00214-7

Nowak, D. J., Greenfield, E. J., Hoehn, R. E., and Lapoint, E. (2013b). Carbon storage and sequestration by trees in urban and community areas of the United States. Environ. Pollut. 178, 229-236. doi: 10.1016/j.envpol.2013.03.019

Nowak, D. J., Hirabayashi, S., Bodine, A., and Greenfield, E. (2014). Tree and forest effects on air quality and human health in the United States. Environ. Pollut. 193, 119-129. doi: 10.1016/j.envpol.2014.05.028

Nowak, D. J., Hirabayashi, S., Bodine, A., and Hoehn, R. (2013a). Modeled PM 2.5 removal by trees in ten US cities and associated health effects. Environ. Pollut. 178, 395-402. doi: 10.1016/j.envpol.2013.03.050

Pataki, D. E., Alig, R. J., Fung, A. S., Golubiewski, N. E., Kennedy, C. A., McPherson, E. G., et al. (2006). Urban ecosystems and the North American carbon cycle. Global Change Biol. 12, 2092-2102. doi: 10.1111/j.13652486.2006.01242.x

Pataki, D. E., Carreiro, M. M., Cherrier, J., Grulke, N. E., Jennings, V., Pincetl, S., et al. (2011). Coupling biogeochemical cycles in urban environments: Ecosystem services, green solutions, and misconceptions. Front. Ecol. Environ. 9, 27-36. doi:10.1890/090220

Pataki, D. E., Emmi, P. C., Forster, C. B., Millsb, J. I., Pardyjakc, E. R., Peterson, T. R., et al. (2009). An integrated approach to improving fossil fuel emissions scenarios with urban ecosystem studies. Ecol. Complexity 6, 1-14. doi: 10.1016/j.ecocom.2008.09.003

Peng, C., Zhang, L., and Liu, J. (2001). Developing and validating nonlinear heightdiameter models for major Tree species of Ontario's boreal forests. North. J. Appl. For. 18, 87-94.

Raciti, S. M., Hutyra, L. R., and Newell, J. D. (2014). Mapping carbon storage in urban trees with multisource remote sensing data: Relationships between biomass, land use, and demographics in Boston neighborhoods. Sci. Total Environ. 500, 72-83. doi: 10.1016/j.scitotenv.2014.08.070

Rao, P., Hutyra, L. R., Raciti, S. M., and Finzi, A. C. (2013). Field and remotely sensed measures of soil and vegetation carbon and nitrogen across an urbanization gradient in the Boston metropolitan area. Urban Ecosyst. 16, 593-616. doi: 10.1007/s11252-013-0291-6

Ren, Y., Wei, X., Wei, X., Pan, J., Xie, P., Song, X., et al. (2011). Relationship between vegetation carbon storage and urbanization: a case study of Xiamen, China. For. Ecol. Manage. 261, 1214-1223. doi: 10.1016/j.foreco.2010.12.038

Rowntree, R. A., and Nowak, D. J. (1991). Quantifying the role of urban forests in removing atmospheric carbon dioxide. J. Arboric. 17, 269-275.

Russo, A., Escobedo, F. J., Timilsina, N., Schmitt, A. O., Varela, S., and Zerbe, S. (2014). Assessing urban tree carbon storage and sequestration in Bolzano, Italy. Int. J. Biodivers. Sci. Ecosyst. Serv. Manage. 10, 54-70. doi: 10.1080/21513732.2013.873822

Sanders, R. A. (1986). Urban vegetation impacts on the hydrology of Dayton, Ohio. Urban Ecol. 9, 361-376. doi: 10.1016/0304-4009(86)90009-4

Seto, K. C., Dhakal, S., Bigio, A., Blanco, H., Delgado, G. C., Dewar, D., et al. (2014). Human Settlements, Infrastructure and Spatial Planning. Intergovernmental Panel on Climate Change. Working Group III- Mitigation of Climate Change. Cambridge; New York, NY: Cambridge University Press.

Seto, K. C., Güneralp, B., and Hutyra, L. R. (2012). Global forecasts of urban expansion to 2030 and direct impacts on biodiversity and carbon pools. Proc. Natl. Acad. Sci. U.S.A. 109, 16083-16088. doi: 10.1073/pnas.1211658109

Soares, A. L., Rego, F. C., McPherson, E. G., Simpson, J. R., Peper, P. J., and Xiao, Q. (2011). Benefits and costs of street trees in Lisbon, Portugal. Urban For. Urban Gree. 10, 69-78. doi: 10.1016/j.ufug.2010.12.001
State Statistical Bureau (SSB) (2014). China Statistical Yearbook. Beijing: China Statistics Press.

Tabacchi, G., Cosmo, L. D., and Gasparini, P. (2011). Aboveground tree volume and phytomass prediction equations for forest species in Italy. Eur. J. For. Res. 130, 911-934. doi: 10.1007/s10342-011-0481-9

United Nations (UN) (2015). World Urbanization Prospects: The 2014 Revision. New York, NY: United Nations Department of Economic and Social Affairs, Population Division.

Wang, C. (2006). Biomass allometric equations for 10 co-occurring tree species in Chinese temperate forests. For. Ecol. Manage. 222, 9-16. doi: 10.1016/j.foreco.2005.10.074

Whitford, V., Ennos, A. R., and Handley, J. F. (2001). "City form and natural process"-indicators for the ecological performance of urban areas and their application to Merseyside, UK. Landsc. Urban Plan. 57, 91-103. doi: 10.1016/S0169-2046(01)00192-X

Whitlow, T. H., Pataki, D. A., Alberti, M., Pincetl, S., Setala, H., Cadenasso, M., et al. (2014). Comments on "Modeled PM 2.5 removal by trees in ten U.S. cities and associated health effects" by Nowak et al. (2013). Environ. Pollut. 191, 256. doi: 10.1016/j.envpol.2014.03.033

Wu, W., Zhao, S. Q., Zhu, C., and Jiang, J. (2015). A comparative study of urban expansion in Beijing, Tianjin and Shijiazhuang over the past three decades. Landsc. Urban Plan. 134, 93-106. doi: 10.1016/j.landurbplan.2014. 10.010

Yang, J., McBride, J., Zhou, J., and Sun, Z. (2005). The urban forest in Beijing and its role in air pollution reduction. Urban For. Urban Gree. 3, 65-78. doi: 10.1016/j.ufug.2004.09.001

Yoon, T. K., Park, C. W., Lee, S. J., Ko, S., Kim, K. N., Son, Y., et al. (2013). Allometric equations for estimating the aboveground volume of five common urban street tree species in Daegu, Korea. Urban For. Urban Gree. 12, 344-349. doi: 10.1016/j.ufug.2013.03.006

Young, G. S., Fox, M. A., Trush, M., Kanarek, N., Glass, T. A., and Curriero, F. C. (2012). Differential exposure to hazardous air pollution in the United States: a multilevel analysis of urbanization and neighborhood socioeconomic deprivation. Int. J. Environ. Res. Public Health 9, 2204-2225. doi: 10.3390/ijerph9062204

Zhang, C., Ju, W., Chen, J. M., Zan, M., Li, D., Zhou, Y., et al. (2013). China's forest biomass carbon sink based on seven inventories from 1973 to 2008. Clim. Change. 118,:933-948. doi: 10.1007/s10584-012-0666-3

Zhao, M., Kong, Z., Escobedo, F. J., and Gao, J. (2010). Impacts of urban forests on offsetting carbon emissions from industrial energy use in Hangzhou, China. J. Environ. Manage. 91, 807-813. doi: 10.1016/j.jenvman.2009. 10.010

Zhao, S. Q., Da, L., Tang, Z., Fang, H., Song, K., and Fang, J. (2006). Ecological consequences of rapid urban expansion: Shanghai, China. Front. Ecol. Environ. 4, 341-346. doi: 10.1890/1540-9295(2006)004 [0341, ECORUE]2.0.CO;2

Zhao, S. Q., Zhu, C., Zhou, D. C., Huang, D., and Werner, J. (2013). Organic carbon storage in China's urban areas. PLoS ONE 8:e71975. doi: 10.1371/journal.pone.0071975

Zhou, D. C., Zhao, S. Q., Liu, S., Zhang, L., and Zhu, C. (2014). Surface urban heat island in China's 32 major cities: spatial patterns and drivers. Remote Sens. Environ. 152, 51-61. doi: 10.1016/j.rse.2014.05.017

Conflict of Interest Statement: The authors declare that the research was conducted in the absence of any commercial or financial relationships that could be construed as a potential conflict of interest.

Copyright (c) 2016 Tang, Chen and Zhao. This is an open-access article distributed under the terms of the Creative Commons Attribution License (CC BY). The use, distribution or reproduction in other forums is permitted, provided the original author(s) or licensor are credited and that the original publication in this journal is cited, in accordance with accepted academic practice. No use, distribution or reproduction is permitted which does not comply with these terms. 